\title{
Determining operational efficiency and capacity building of vegetable growers installed drip irrigation systems
}

Syed Muhammad Zakria ${ }^{1 *}$ and Muhammad Bilal ${ }^{1}$

1. Institute of Agricultural Sciences, University of the Punjab, Lahore-Pakistan

*Corresponding author's email: smzakrial@yahoo.com

Citation

Syed Muhammad Zakria and Muhammad Bilal. Determining operational efficiency and capacity building of vegetable growers installed drip irrigation systems. Pure and Applied Biology. Vol. 10, Issue 4, pp1312-1325.

http://dx.doi.org/10.19045/bspab.2021.100136

Received: $17 / 12 / 2020 \quad$ Revised: 19/02/2021

Accepted: 22/02/2021

Online First: 13/03/2021

\section{Abstract}

Drip Irrigation System is the most efficient irrigation water saving initiative. Technical know-how, capacity building of beneficiaries is prerequisite for sustainable adoption, mitigating minor repair and efficient running of the system. The data pertains to the year ending Dec 2018 of vegetable growers installed Drip Irrigation System in Rawalpindi district Punjab Pakistan. The district having in total 27 sites have taken up for study. The data collected through validated questionnaires in person from 135 acres vegetable grown, 108 acres 4 acres from each 27 sites under drip irrigation and 27 acres, 1 acre with conventional irrigation system, and analyzed using Statistical Package for Social Sciences (SPSS) Descriptive analysis summarized by applying Student's tTest. The research concludes that $100 \%$ vegetable growers preferred to go for Drip Irrigation System. The ultimate objective, water productivity increased by $15.55 \mathrm{~kg} / \mathrm{m}^{3}$. As regards operational efficiency $38.5 \%$ facing problem in filtration unit, $31.1 \%$ in distribution unit and 5.2\% in pumping unit. Repair is being carried out $59.25 \%$ by companies. It is assessed, for capacity building only one day training was organized for $77.78 \%$ and none for $22.22 \%$ pathetically. Crop production plan was provided by the companies to $85 \%$ beneficiaries, substance wise $52.17 \%$ growers considered good, $3.48 \%$ very good, only $4.55 \%$ found the best and $44 \%$ placed the backup services as poor. Majority 52\% suggested to hold 3-5 days session. 8\% proposed for upscaling the existing DIS with computerized one, $7 \%$ demanded for enhanced warranty period covering 5 years and $15 \%$ for provision of electricity.

Keywords: Capacity building; Drip irrigation system; Operational efficiency; Operation and Maintenance; Punjab; Pakistan; Rawalpindi

\section{Introduction}

Pakistan Provincial Water Accord (PWA) 1991, reveals that for Punjab surface water allocation is 55.94 Million Acre Feet against the total availability of Pakistan 107 MAF. Whereas, province is actually receiving 50 MAF for 59500 outlets at tertiary level. Substantial amount $21 \mathrm{MAF}$ is lost due to uneven fields and poor farm layout, approximately 33 MAF is added by mining ground water resources. Even then only 53 MAF remains available for the use leaving behind the shortfall of 12 MAF against 65 MAF, the actual crop water requirement to maintain cropping intensity $150 \%$ [1]. 
Consequently, due to deficiency of $12 \mathrm{MAF}$ the agricultural productivity is much lower than the international yard sticks and in comparison with neighboring countries too. For sustainable use of diminishing resources (Land, Water and Environment) the strategy must incorporate along with others irrigation water saving innovative interventions, the ground water recharge, recycle and reuse of drainage [2].

It is pertinent to mention that ground water has contributed huge share in the development of agriculture and rural economy of Pakistan. Ground water extraction has been risen exorbitantly 50$60 \%$, has increased five times during the period 1985-2015 throughout the Punjab, Pakistan. In rain fed tracts of northern Punjab mainly Agriculture has to rely on ground water over drafting. If we figure out the present status of tube wells in the Province which is over 1.04 million with total water exploiting about 33 MAF. Inclusive of diesel operated 0.90 million and electricity operated 0.14 million tube wells, consuming monstrous fuel and energy resources and causing environmental degradation as well [3]. Therefore, under the peculiar circumstances paradigm shift from inefficient inexact to exact agri practices are required through adoption of innovative irrigation water saving initiatives. The irrigation efficiency is all about High Efficiency Drip Irrigation Systems (DIS), considered as one of the most efficient irrigation method in addition to better weed control, effective use of fertilizer and other nutrients required for plants growth. Primarily DIS focusing at water and other inputs applications slowly, regularly and frequently to the effective root zone of plant at various growth stages. Regular periodical maintenance, cleaning and flushing is also essential for running the system efficiently. Capacity building is equally important for the adoption of irrigation water saving interventions and to mitigate minor repair [4]. The present participatory study is conducted during the year ending December 2018. One of the objectives is to evaluate the operational efficiency, capacity building and backup service provision to vegetable growers in District Rawalpindi who installed the Drip Irrigation Systems. The facility is extended as High Efficiency Irrigation Systems (HEISs) component under the on-going Punjab Irrigated-Agriculture Productivity Improvement Project (PIPIP) On Farm Water Management lead Project of the Punjab Agriculture Department. The present research is carried out as one and only meaningful vigilance without conflict of interest other than the stake holder entities and also evaluation for reorientation of decision makers to incorporate corrective measures if required at the most appropriate time. And to provide food for thought to the researchers and implementing agencies in devising strategies in future for sustainable adoption of water saving innovations too.

\section{Materials and Methods}

The city Rawalpindi is adjacent to country capital Islamabad at an elevation 508 meter above sea level as country $4^{\text {th }}$ largest city with population 5.46 million. The district fulfills the share from vegetables and fruits $74.5 \%$ and $25.5 \%$ respectively, remaining requirement is met from the produce of adjoining districts. Main vegetables grown are cucumber, tomato, potato, cabbage, onion and cauliflower. District Rawalpindi, Punjab Pakistan, is selected for the study. The entire district is covered, having in total 27 sites adopted Drip Irrigation Systems (DIS) for vegetable cultivation. 135 acres data is collected, 108 acres, 4 acres from each site under DIS and 27 acres, 1 acre adjacent to DIS as control /conventionally irrigated taken for perception-based study. Authenticated complete list along with particulars is obtained from OFWM District office and 
data were collected with the collaboration of field staff. The data pertains to year ending December 2018, collected through validated questionnaire in person at the doorstep of farmers. Triangulation approach is used, objectives are taken as dependent variables, and independent variables such as education level, operational issue, capacity building also taken into consideration. Quantitative data were analyzed using Statistical Package for Social Sciences (SPSS). Descriptive statistics including frequencies, percentages, means, and standard deviations were used to summarize different variables by applying Student's t-Test.

\section{Results and Discussion}

It holds valid reasons to believe that education is proven source to increase knowledge, enhance awareness and wisdom $[5,6]$ concluded education had significant positive impacts on adoption of improved farm practices.

\section{Education}

The data collected during the research as (Fig. 1) revealed that lowest level in adoption of DIS is primary level education, then intermediate, then comes matric level and highest percentage possess graduation level. Percentages figured out are as $3.7 \%, 18.5 \%$, $26.7 \%$ and $51.1 \%$ respectively. The results are similar to $[7,8]$ conclusion is drawn without shadow of doubt that education has significant positive impact on adoption of water saving interventions, drip irrigation systems in the case.

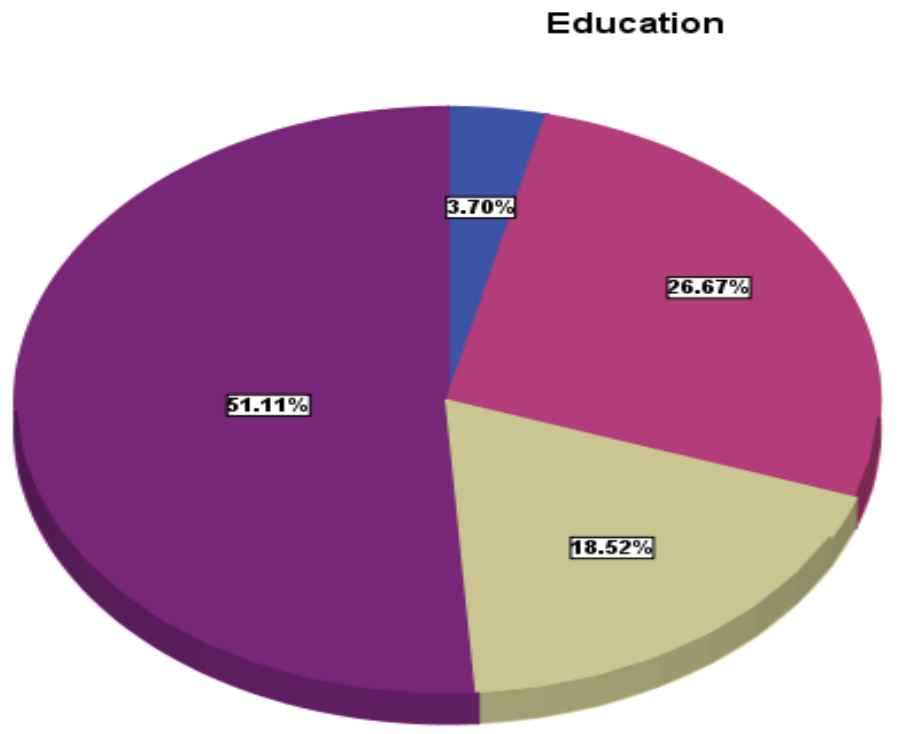

Figure 1. Education level of the respondents

\section{Land holding and income}

It is estimated by [9] that HEIS's adopters belong to relatively wealthy, having higher average farm size of vegetable growers 2.10 acres in Punjab Province. During the research it is assessed average holding in the Rawalpindi District remained higher 5.48 acres (DIS adopters vegetable growers only). It is concluded that DIS owners possess higher education, are wealthy and have higher awareness level profile. These results are similar to $[8,10,11]$ that education, land holding, farm size have positive impact on adoption of DIS.

\section{Water productivity increase}

It is assessed during the study conducted, reflected in (Table 1) water productivity with DIS 21.55 and with control/conventional 
irrigation method is 6.00 difference of means is $15.55 \mathrm{~kg} / \mathrm{m}^{3}$ ( $\mathrm{t}$ value 27.90 and $\mathrm{p}$ value 0.000 ). Increase $15.55 \mathrm{~kg} / \mathrm{m}^{3}$ in water productivity the ultimate objective of each water saving intervention is highly significant and is quite handsome incentive for the beneficiaries for sustainable adoption of innovative initiatives.

The increase in land and water productivity is in line with various researches conducted already such as [12-15]. Increased Water Productivity is also contributing positively in terms of WUE, socio economic status, sustainable environment and sustainable agriculture too.

Different HEISs methods and availability of spare parts

It was revealed during the course of research that $100 \%$ respondents (vegetable growers in District Rawalpindi) opted DIS, the question asked pertaining to cost comparison, easy operation, better yield, requiring repair, availability of parts was absolutely positive for DIS and hence dispensed with.

\section{Operational efficiency}

As for as operational efficiency is concerned in (Table 2) is reflecting the frequency of problems. Respondents facing post installation of DIS depicted the owners facing problems mostly pertains to filtration unit $38.5 \%$, then distribution unit $31.1 \%$ then come pumping unit $5.2 \%$ and lastly $5.2 \%$ facing no problems so far after installation the DIS at their farms.

\section{Repair carried out and problems}

The analysis reflects in case of problems repair is carried out $59.25 \%$ by the company, $36.11 \%$ by themselves and $4.63 \%$ narrated that minor repair was carried out with the guidance of department. It is worth mentioning that 30 Services and Supply
Companies supplying HEIS system throughout Punjab province have entered into agreement (as per prescribed terms and conditions) to provide post installation follow up services for two years.

\section{Provision of training regarding DIS}

Results in (Table 2) describes the provision of training $77.78 \%$ responded one-day training was held at the time of installation of the system at their farms and $22.22 \%$ replied no capacity building training session was arranged at all, which is dismal and embarrassing at the part of SSCs, which could not manage one-day training even inspite of gaining business from it.

Such negligible training occasions would not provide the skill and insight required for $\mathrm{O} \&$ $M$ enhancing operational efficiency for the DIS system owners. It is serious threat for sustainability of the on-going programmer as well.

Provision of production plan to DIS users

The beneficiaries were asked regarding the provision of production plan, by whom it was provided and the extent of utility of the stuff. Results in (Table 3) revealed that $85 \%$ responded yes but $15 \%$ refrained that no backup brochure/booklet, literature for crop designed was provided. Similarly, upon asking from whom it was provided $85 \%$ replied that plan was provided by the company but $15 \%$ respondents conveyed nobody provided such plan at all.

Further, upon asking the usefulness of plan $52.17 \%$ found good, $43.45 \%$ found very good and only $4.35 \%$ placed the literature as the best. But the facts remained there that adequate knowledge of the crop and necessary skill for $\mathrm{O} \& \mathrm{M}$ of DIS is prerequisite for sustainable adoption of HEISs [16]. 
Table 1. Comparison between HEIS method and Conventional method regarding increase in water productivity

\begin{tabular}{|c|c|c|c|c|c|c|c|c|c|c|c|}
\hline \multirow[t]{2}{*}{ Statement } & \multicolumn{4}{|c|}{ Descriptive statistics } & \multicolumn{2}{|c|}{ Relationship } & \multicolumn{3}{|c|}{ Difference } & \multirow{2}{*}{$\begin{array}{c}\text { t } \\
\text { Value }\end{array}$} & \multirow{2}{*}{$\begin{array}{c}\text { P } \\
\text { Value }\end{array}$} \\
\hline & Mean & $\mathbf{N}$ & SD & SE & $\mathbf{r}$ & $\begin{array}{c}\text { P- } \\
\text { value }\end{array}$ & Mean & SD & $\mathbf{S E}$ & & \\
\hline $\begin{array}{l}\text { Q21a Water productivity } \\
\text { increase - HEIS } \mathrm{kg} / \mathrm{m}^{3}\end{array}$ & 21.55 & 135 & 7.65 & 0.66 & 0.736 & 0.000 & 15.55 & 6.47 & 0.56 & $27.90 * *$ & 0.000 \\
\hline $\begin{array}{l}\text { Q21b Water productivity } \\
\text { increase - Conv. } \mathrm{kg} / \mathrm{m}^{3}\end{array}$ & 6.00 & 135 & 1.75 & 0.15 & & & & & & & \\
\hline
\end{tabular}

NS = Non-significant $(\mathrm{P}>0.05) ; *=$ Significant $(\mathrm{P}<0.05) ; * *=$ Highly significant $(\mathrm{P}<0.01)$

$\mathrm{r}=$ Pearson's correlation

$\mathrm{SD}=$ Standard deviation

$\mathrm{SE}=$ Standard error 
Table 2. Distribution of respondents regarding problems for HEIS's, resolution and training provision

\begin{tabular}{|c|c|c|c|}
\hline & & Count & Column N \% \\
\hline \multirow{5}{*}{$\begin{array}{l}\text { Q28 Problem facing after } \\
\text { installation of DIS }\end{array}$} & No problem & 7 & $5.2 \%$ \\
\hline & Pumping unit & 7 & $5.2 \%$ \\
\hline & Filtration unit & 52 & $38.5 \%$ \\
\hline & Distribution unit & 42 & $31.1 \%$ \\
\hline & Other & 0 & 0 \\
\hline \multirow{4}{*}{$\begin{array}{l}\text { Q29 How repair carried out in case } \\
\text { of problem }\end{array}$} & Self & 39 & $36.11 \%$ \\
\hline & Department & 5 & $4.63 \%$ \\
\hline & Company & 64 & $59.25 \%$ \\
\hline & Other & 0 & $0.0 \%$ \\
\hline \multirow{2}{*}{$\begin{array}{l}\text { Q30 Provided training on } \\
\text { installation of the system }\end{array}$} & Yes & 21 & $77.78 \%$ \\
\hline & No & 6 & $22.22 \%$ \\
\hline
\end{tabular}

Table 3. Distribution of respondents regarding their views about production plan with respect to HEIS

\begin{tabular}{|c|c|c|c|}
\hline \multicolumn{2}{|c|}{} & Count & Column N \% \\
\hline \multirow{3}{*}{ Q32 Provide production plan } & Yes & 23 & $85 \%$ \\
\cline { 2 - 4 } & No & 4 & $15 \%$ \\
\cline { 2 - 4 } & Other & 0 & $0.0 \%$ \\
\hline \multirow{4}{*}{ Q33 Who provide production plan } & N.A. & 4 & $15 \%$ \\
\cline { 2 - 4 } & OFWM Wing & 0 & $0.0 \%$ \\
\cline { 2 - 4 } & Company & 23 & $85 \%$ \\
\cline { 2 - 4 } & Other & 0 & $0.0 \%$ \\
\hline \multirow{2}{*}{$\begin{array}{c}\text { Q34 Benefits of provided produciton } \\
\text { plan }\end{array}$} & Good & 12 & $52.17 \%$ \\
\cline { 2 - 4 } & Very good & 10 & $43.48 \%$ \\
\cline { 2 - 4 } & Best & 1 & $4.35 \%$ \\
\hline
\end{tabular}

Recommended by Madhava and Surendran [11] the need of technical support, capacity building for operational efficiency and maintenance of DIS. [17] emphasized that farmers should possess adequate knowledge and skill for the maintenance of the Drip System at field level as a prerequisite. [18] in report of Capacity Building observed the importance of Drip Irrigation System maintenance, Drip Capacity and Management initiative vital for maximizing productivity. It is observed by [19] capacity building has significant impact alongside others, training programs helped farmers to exploit full potential of Drip Irrigation System as quite convincing. To achieve "MORE CROP PER DROP" more training session be carried out he added. Therefore, it is concluded that due importance and focus must be given, under-estimating the due diligence could be disastrous.

Comparison of weed control and easiness As regards efficiency in weed control through DIS and control/conventional irrigation methods $100 \%$ responded that DIS is helpful to control weed efficiently and effectively. None opted for No. and upon asking for easiness comparison of both systems responses are determined as (Table $4)$.

Through DIS $75.6 \%$ considered very easy, $24.4 \%$ easy and 0 for difficult. Whereas through Conventional Irrigation Method $88.9 \%$ found difficult, $11.1 \%$ easy and 0 
some considered very easy weed control. The results also found highly significant with mean difference 1.644 of both DIS and control method having $t$ value 37.42 and $p$ value 0.000 . The (Table 5) is placed below for ready reference.

The similar results have concluded by $[1,14$, 20] claiming that efficient and better weed control goal is achieved. [21] further added with better control of weeds cost of production is decreased.

\section{Enhancing crop production with DIS}

Absolute chunk $100 \%$ beneficiaries were convinced, motivated and responded positively that HEISs/DIS adoption proved helpful in increasing crop production, yield of vegetables have been enhanced substantially.

The (Table 6) narrates assessment level of easiness with DIS in increasing productivity $71.1 \%$ taken it very easy, $28.9 \%$ easy and again none found difficult. Majority of the growers $80.7 \%$ are of the opinion that enhancing vegetables crop yield with conventional irrigation methods is difficult while $19.3 \%$ thought it easy and nobody opted for very easy.

Similar positive impacts have been determined by the researchers around the globe such as [8] water saving interventions have enhanced the productivity. [22] World
Bank Group concluded, efficient and judicious use of water enhanced 40-110\% yield. NIAB assessed 52\% yield increased, [9] 100\% crop yield increased, [23] reported $50 \%$ increase with Micro Irrigation Systems. [24] further added not only increase in quantity but quality of the crop as well.

\section{Suggested procedural changes}

While expressing views pertaining to satisfaction level regarding the on-going OFWM lead PIPIP the beneficiaries (vegetable growers) desired modifications in existing procedure. It was estimated in (Fig. 2) that $89.63 \%$ respondents desired to have procedural changes and only $10.37 \%$ very thin percentage is satisfied over the implementation procedure in vogue.

In contexts with specific reference of objectives Operational Efficiency and Capacity Building DIS owners suggested the following.

\section{i) Training duration}

Respondents were dissatisfied over holding one-day training only at their farms at the juncture of installation of Drip Irrigation System (DIS), they suggested different duration like 3-5 days, 6-7 days, 8-10 days having percentages $52 \%, 44 \%$ and $4 \%$ respectively. The (Fig. 3) is reflecting the proposed duration by the beneficiaries.

Table 4. Distribution of respondents regarding their views about weeds control by HEIS and Conventional methods

\begin{tabular}{|c|c|c|c|}
\hline & & Count & Column N \% \\
\hline \multirow{3}{*}{ Q39ia Weeds control - HEIS } & Difficult & 0 & $0.0 \%$ \\
\hline & Easy & 33 & $24.4 \%$ \\
\hline & Very easy & 102 & $75.6 \%$ \\
\hline \multirow{3}{*}{ Q39ib Weeds control - Conventional } & Difficult & 120 & $88.9 \%$ \\
\hline & Easy & 15 & $11.1 \%$ \\
\hline & Very easy & 0 & $0.0 \%$ \\
\hline
\end{tabular}


Table 5. Comparison between HEIS method and Conventional method regarding weed control

\begin{tabular}{|c|c|c|c|c|c|c|c|c|c|c|c|}
\hline \multirow[t]{2}{*}{ Statement } & \multicolumn{4}{|c|}{ Descriptive statistics } & \multicolumn{2}{|c|}{ Relationship } & \multicolumn{3}{|c|}{ Difference } & \multirow{2}{*}{$\begin{array}{c}\mathbf{t} \\
\text { Value }\end{array}$} & \multirow{2}{*}{$\begin{array}{c}\mathbf{P} \\
\text { Value }\end{array}$} \\
\hline & Mean & $\mathbf{N}$ & SD & SE & $\mathbf{r}$ & P-value & Mean & SD & SE & & \\
\hline Q39ia Weeds control - HEIS & 2.756 & 135 & 0.431 & 0.037 & 0.091 & 0.292 & 1.644 & 0.511 & 0.044 & $37.42 * *$ & 0.000 \\
\hline $\begin{array}{c}\text { Q39ib Weeds control - } \\
\text { Conventional }\end{array}$ & 1.111 & 135 & 0.315 & 0.027 & & & & & & & \\
\hline
\end{tabular}

NS = Non-significant $(\mathrm{P}>0.05) ; *=$ Significant $(\mathrm{P}<0.05) ; * *=$ Highly significant $(\mathrm{P}<0.01)$

$\mathrm{r}=$ Pearson's correlation

$\mathrm{SD}=$ Standard deviation

$\mathrm{SE}=$ Standard error

Table 6. Distribution of respondents regarding their views about increase in production by HEIS and Conventional methods

\begin{tabular}{|c|c|c|c|}
\hline & & Count & Column N \% \\
\hline \multirow{2}{*}{ Q40 HEIS helpful to improve production } & Yes & 135 & $100.0 \%$ \\
\hline & No & 0 & $0.0 \%$ \\
\hline \multirow{3}{*}{ Q41a Comparison easiness crops - HEIS } & Difficult & 0 & $0.0 \%$ \\
\hline & Easy & 39 & $28.9 \%$ \\
\hline & Very easy & 96 & $71.1 \%$ \\
\hline \multirow{3}{*}{ Q41b Comparison easiness crops - Conv } & Difficult & 109 & $80.7 \%$ \\
\hline & Easy & 26 & $19.3 \%$ \\
\hline & Very easy & 0 & $0.0 \%$ \\
\hline
\end{tabular}




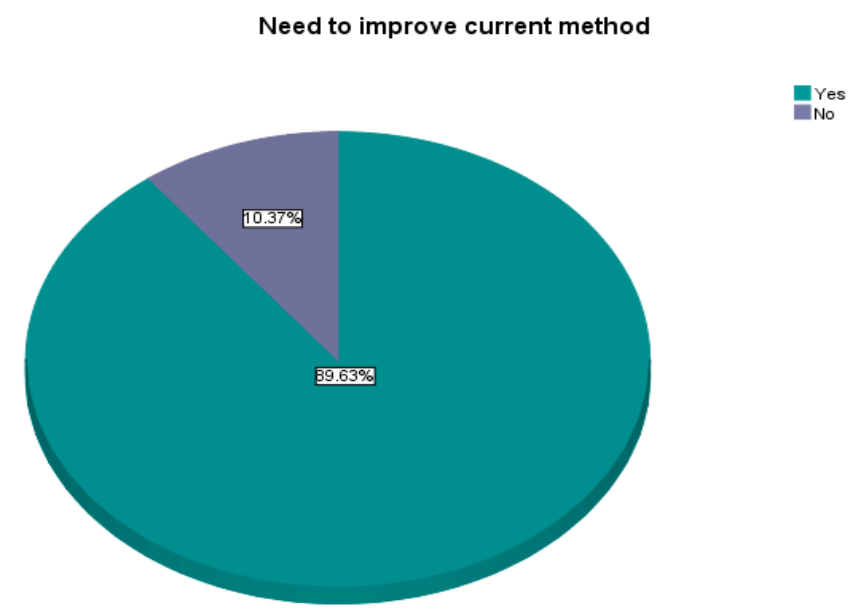

Figure 2. Views of the respondents regarding improvement in Current HEISs/DIS procedure

\section{Training Duration}

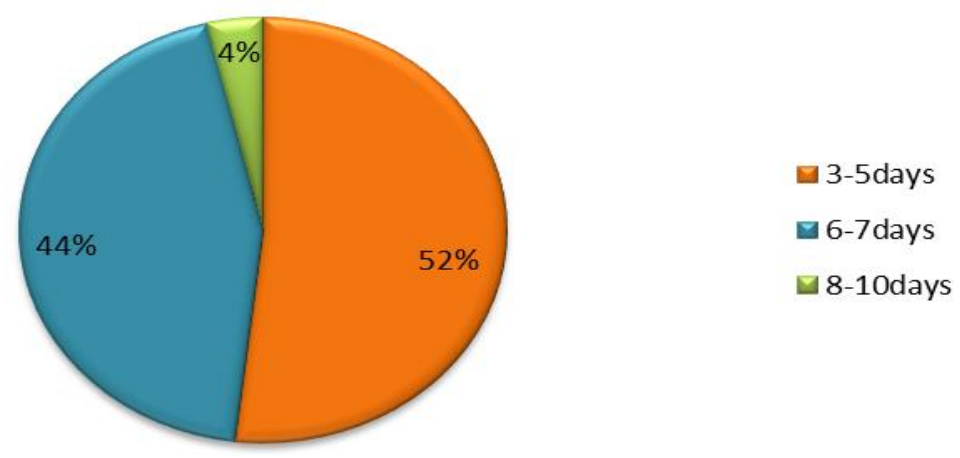

Figure 3. Respondents views regarding duration of training

\section{ii) Training place}

Responses regarding whether training sessions should be held at farm site, office or in Farmers Training Centres (FTC) supposed to be established at Multan and Rawalpindi, as a satellite stations of Water Management Training Institute Lahore but both are nonfunctional yet (December 31, 2018). The feedback is summarized below in (Fig. 4) with percentages as office plus site $52 \%$, at site $44 \%$ and at FTC 4\%. Capacity building of all stakeholders carries immense importance holding one-day training only is highly insufficient. It seems that authorities have emphasized on hardware only and software portion have been neglected. [11] determined the Farmers education regarding the innovative technologies as pragmatic approach to alleviate poor performance of agri. sector. [25] expressed Capacity building training of aligned stakeholders and precise technical knowhow to all emphasized. [26, 27] were also of view that adequate knowledge be disseminated to the concerned for successful implementation of innovative irrigation water saving technologies.

\section{iii) Booklet/brochure utility}

The respondents were asked to share their views regarding utility of brochures as satisfactory, poor and very poor. Feedback is assessed in (Fig. 5) as 22\%, 48\% and 30\% respectively, indicating that majority $48 \%$ observed that literature provided to them regarding Operation and Maintenance $(\mathrm{O} \&$ 
M) of Drip Irrigation System (DIS) could be described poor which is again pathetic and requires immediate attention of decision makers for improvement.

iv) Nature of production plan

The results estimated in (Fig. 6) to cope with the requirement under crop specific, crop diversification, need for experts hiring as $26 \%, 37 \%$ and again $37 \%$ respectively. Prime objective of such irrigation water saving interventions is crop diversification, paradigm shift from general to more profitable crops. [9] have pointed out inadequate capacity of SSCs to cater the need of farming community. [28] considered the lack of technical knowledge, capacity building of staff engaged with and farmers particularly as critical factor. [13] added Effective capacity building enhancing the farmer's skill to mitigate system repair. [18] determined capacity building and management initiative imperative for maximizing productivity.

v) Backup services

Farmers feedback was recorded regarding the provision of backup services available to them by the SSCs and relevant stakeholders, executing agency, categorized as satisfactory, poor and very poor as (Fig. 7), the percentages of their responses are $19 \%$, $44 \%$ and $37 \%$ respectively, which lead us to conclude beneficiaries desired to revisit the software component, to cater the need of crop diversification and at least backup services in resolving site specific problems for sustainable adoption of initiative, for efficient running of the system (DIS) and for sustainable agriculture too.

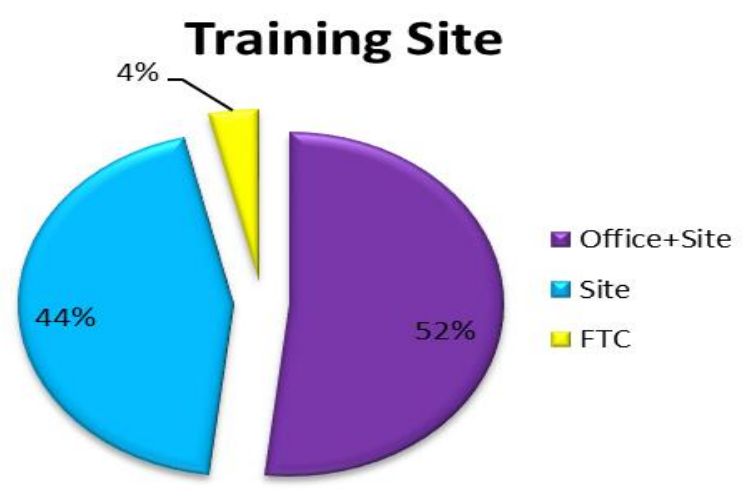

Figure 4. Respondents views regarding the training site

\section{Broucher/Booklet usefulness}

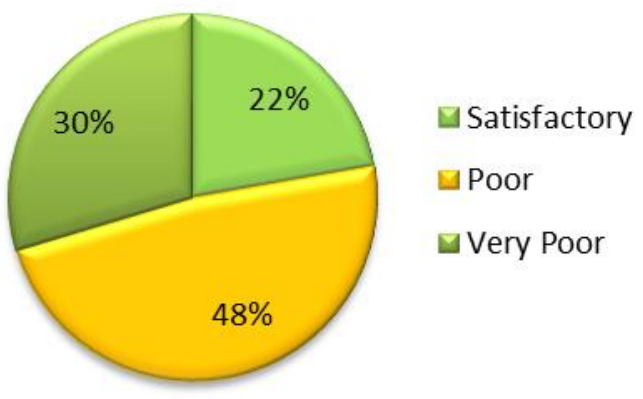

Figure 5. Respondents views regarding the usefulness of brochures 


\section{Production plan}

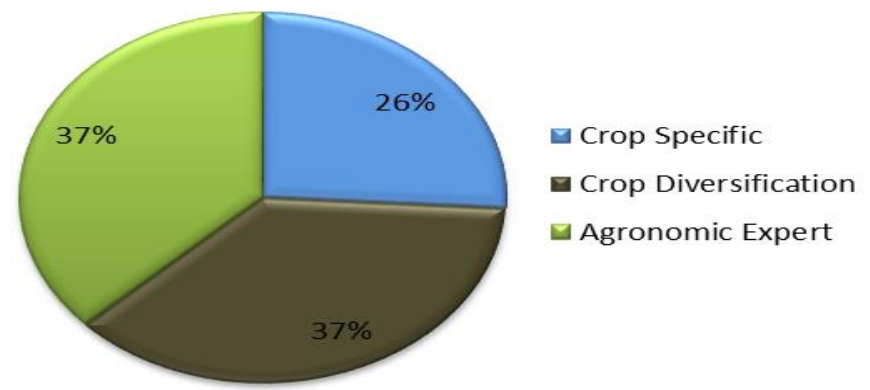

Figure 6. Respondents views regarding production plan

\section{Backup Services}

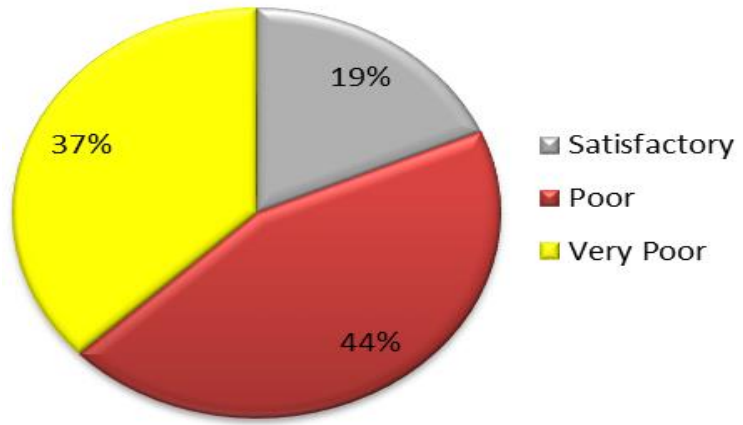

Figure 7. Respondents views regarding backup services

\section{Proposal/ suggestions in addition}

The vegetable growers of district Rawalpindi who had DIS installed at their farms were invited to put forward proposals/suggestions based on their experiences other than mentioned above for refinement of on-going HIESs component to make it farmer friendly by addressing the impediments.

In total 6 suggestions were floated by the beneficiaries based on their experiences, those are i) uplifting of existing HIESs with computerized one by $8 \%$ ii) crop expert hiring by SSCs $30 \%$ iii) high tunnel provision for crop diversification $11 \%$ iv) marketing infrastructure improvement $7 \% \quad \mathrm{v})$ replacement of electric motor by $\mathrm{SSCs}$ in emergency till 5 years $7 \%$ vi) electricity provision as energy source instead of diesel for tube wells operation $15 \%$ vii) and finally 6 respondents $22 \%$ surprisingly had not been able to present any suggestion.
I) In brief, $30 \%$ beneficiaries as summarized in (Fig. 8) emphasized, for hiring of crop experts for specific crop designed and further to cope with the crop diversification requirement literature provision to the innovators and early adopters. [29] concluded also to integrate the allied wings and to reinforce the Agri. Extension Services for viable solutions. It is high time for the government to revisit the policies by binding both executing agency and SSCs liable to provide meaningful, the efficient and productive follow up services.

II) No doubt HEISs, DIS is newly introduced technology since 8 years back under the umbrella of On-Farm Water Management Punjab, in the Punjab Province, it is also fact it requires high initial cost but proposal put forward by the beneficiaries $11 \%$ indicating the fact that they are convinced and motivated for adoption and to avail advantages of initiative launched by the 
Government so far. Beneficiaries suggested that Government should exhibit flexibility if some farmers intend to go for high tunnel due to obvious reasons of yield increase or to cope with crop diversification the existing walk-in tunnel specifications do not address the issues.

III) Marketing infrastructure improvement was also demanded by $7 \%$ DIS system holders which is quite genuine until and unless the produce of the farmers is disposed of properly, in time and appropriately, improvement in socio-economic status will remain below the satisfactory level. It will not only hamper his future plans inclusive of timely next crop sowing but will have negative impact on overall economy of the area. The [30] has taken marketing infrastructure as integral part of viable agriculture.

IV) Replacement of electric motor in case of emergency in summer by SSCs till 5 years is also proposed by the $15 \%$ respondents to avoid detrimental impact on cultivated vegetables/crops, which seems difficult in existing terms and conditions (warranty period covering 2 years after installation) which could be looked into sympathetically. Or some other interim arrangement could be in position at each District level by the SSCs continue working with On Farm Water Management Wing, Punjab Agriculture Department.

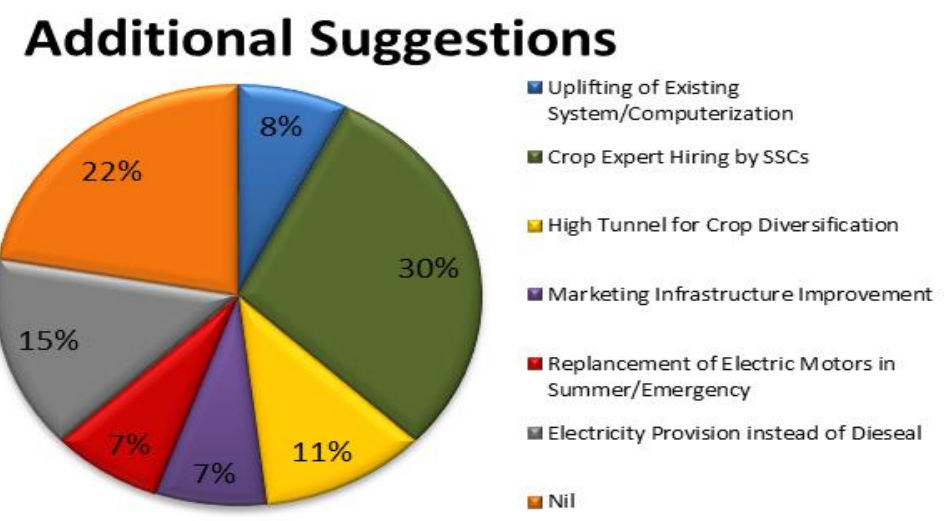

Figure 8. Respondents additional suggestions/proposal

\section{Conclusion}

The study concludes $100 \%$ vegetable growers have gone for adoption of DIS as the most efficient irrigation water saving interventions, water productivity have increased by $15.55 \mathrm{~kg} / \mathrm{m}^{3}$ significantly. As regards operational efficiency $38.5 \%$ facing problems in filtration unit, $31.1 \%$ in distribution unit, $5.2 \%$ in pumping unit. Repair is being carried out by companies $59.25 \%$ and $36.19 \%$ self. Only one-day capacity building training was arranged for $77.78 \%$ and none for $22.22 \%$ which is pathetic. Crop production plan was given to $85 \%$ and nothing for $15 \%$. The plan was provided $85 \%$ by SSCs companies, $15 \%$ denied the provision of requisite literature. $52.17 \%$ vegetable growers found the substance good, $43.48 \%$ very good and only $4.35 \%$ found the best. Majority $89.63 \%$ respondents desired to have changes in ongoing project implementation procedure. In context of training duration $52 \%$ proposed to hold 3-5 days session, 52\% suggested to arrange such capacity building sessions both in office and at site, 44\% system holders found the backup services poor. Responses to further suggestions were concluded as $8 \%$ proposed upscaling the existing DIS with computerized one, $7 \%$ for enhanced warranty 
period backup services, $15 \%$ demanded provision of electricity and $22 \%$ had no proposal. Therefore, installation of DIS only might not suffice, combination of hardware coupled with software component such as upscaling operational efficiency and capacity building of stakeholders is emphasized to ensure sustainable food security and judicious use of diminishing resources as well.

\section{Authors' contributions}

Conceived and designed the experiments: SM Zakria \& M Bilal, Performed the experiments: SM Zakria, Analyzed the data: SM Zakria, Wrote the paper: SM Zakria.

\section{Acknowledgement}

Thankful to farmers participated in perception-based research and for provision of requisite comprehensive information. Thanks also to Mr. Muhammad Saqib Sohail \& Mr. Ahmad Zakria for composing manuscript with zeal.

\section{Reference}

1. Directorate General Agriculture (Water Management) (2017). Punjab IrrigatedAgriculture Productivity Improvement Project (PIPIP)-Revised. Government of the Punjab, Agriculture Department through the World Bank. Directorate General Agriculture (Water Management) Punjab, Lahore, Pakistan.

2. Government of Pakistan (2017-18). Ministry of Statistics (Statistics Division). Pakistan Development Statistics, Pakistan Bureau of Statistics, Islamabad, Pakistan.

3. Punjab Development Statistics (201718). P \& D Department. Government of the Punjab, Lahore, Pakistan.

4. Irrigation and Green Industry (2017). Can you do drip. IGIN (https//igin.com/articles.sec66irrigation.html).

5. Khan CZA (1994). Prospects for effective institutional and functional linkages between agriculture research, extension and farming communities in Balochistan. National workshop on linkages between Agricultural Research, Extension and Farming Communities, Deciduous Fruit Development Center, Quetta, Pakistan.

6. Mirza \& AH (1994). Diffusion and adoption of innovations. National Book Foundation, Islamabad, Pakistan.

7. Hassan MZY (1991). A study into the adoption of plant protection measures among the mango growers of tehsil Mazaffargarh. M.Sc. (Hons.) Thesis, University of Agriculture, Faisalabad, Pakistan.

8. Mahmood N, Ali T, Ahmad M \& Maan AA (2012). Impact assessment of adoption of water saving irrigation interventions on the socio-economic development of small farmers in district faisalabad. J Agri Res 50(1): 155-162.

9. Monitoring and Evaluation Consultants (2018). Punjab Irrigated-Agriculture Productivity Improvement Project (PIPIP) Impact Assessment Report 201718. MM Pakistan (Pvt.) Ltd, Lahore, Pakistan.

10. Ibrahim M, Idrees \& M (1993). Agricultural credit role in the development of agriculture. $J$ Rural Develop Admin 25(4): 67-74.

11. Madhava CK \& Surendran U (2016). Study on factors influencing the adoption of drip irrigation by farmers in humid tropical kerala, india. Int J Plant Prod 10(3): 347-364.

12. Bhattarai M (2008). Socio-economic impact of low-cost tank with drip irrigation for vegetable production. A community-scale case study in Nepal. XIIIth World Water Congress 1-4 September, Montpellier, France.

13. Jha Bk, Mali SS, Naik SK \& Sengupta T (2017). Yield, water productivity and economics of vegetable production under drip and furrow irrigation in Eastern 
Plateau and Hill Region of India. Int $J$ Agr Sci Res 7: 43-50.

14. Kerstein A (2015). The impact of drip irrigation: "more crop per drop". Borgen Magazine

(https://www.borgenmagazine.com/impa ct-drip-irrigation-crop-per-drop).

15. Mali S (2016). Basic concepts of water productivity. Indian Council for Research.

16. Latif M, Haider SS \& Rashid MU (2016). Adoption of high efficiency irrigation system (heiss) to overcome scarcity of irrigation water in pakistan. Proceedings of Pakistan Academy of Sciences, B. Life Environ Sci 53(4): 243-252.

17. Keller J \& Blisner RD (1990). Sprinkler and trickle irrigation. Chapman and Hall, New York, USA.

18. Kakumanu K, Palanisami K \& Adinarayana G (2015). Capacity building on drip irrigation system in dryland system. CGIAR, Research Program on Dryland Systems.

19. Palanisami K, Ranganthan CRR, Suresh KD \& Malik RPS (2014). Enhancing the crop yield through capacity building programs in tamil nadu state, india. Agri Sci 5(1): 33-42.

20. Shaik MSR \& Mistry JJ (2018). Socioeconomic impact of adoption of drip irrigation system on drip owners of aravalli district. Int J Microbiol Appl Sci Special Issue-6: 2174-2180.

21. Pooja P, Dhobale P, Asmabi S \& Priyanka N (2017). Future of drip irrigation system. A proposed approach. Multidscip J Res Eng Technol 4(1): 10551060.

22. International Finance Corporation (2014). Impact of efficient irrigation technology on small farmers. World Bank Group.
23. Gunaratne LHP, Ekanayake EMT \& Gunawardne ERN (2006). Technical and socio-economic assessment of micro irrigation systems in the small-scale farming sector of sri lanka. Trop Agric Res 18: 3-9.

24. Byelich B, Cook J \& Rowley C (2019). Small acreage irrigation guide. Water rights and irrigation management. United States Department of Agriculture, Colorado State University USA.

25. Mohsin RM (2013). Threat to agriculture in pakistan and their remedies under pakistani environment. IOWA State University, USA.

26. Levidow L, Zaccaria D, Maia R, Vivas E, Todorovic M \& Scardigno A (2014). Improving water efficient irrigation. Prospects and difficulties of innovative practices. Agric Water Manage 146: 8494.

27. Rosenbaum A \& Markovitz E (2012). Drip irrigation-a key pillar in sustainable productivity. Development Asia. Session 6b: Tools, Techniques, Innovations (https://events.development.asia/system/ files/materials/2012/04/201204-dripirrigation-key-pillar-sustainableproductivity.pdf).

28. CPWF (2013). Optimizing crop production with drip irrigation. Colombo, Sri Lanka.

29. Steduto P, Hsiao TC, Fereres E, \& Raes D (2012). Crop yield response to water. Food and Agriculture Organization of the United Nations. Rome.

30. IDE (2003). Poverty reduction through irrigation and smallholder markets (prism). Value-chains (http://www.valuechains.org/dyn/bds/docs/213/ide prism manual draft 9-03.pdf). 